\title{
1 Mercury loading within the Selenga River Basin and Lake 2 Baikal, Siberia
}

4 Roberts, S. ${ }^{\text {a b }}{ }^{*}$, Adams, J.K. ${ }^{\text {c d }}$ *, Mackay, A.W. ${ }^{\text {d }}$, Swann, G.E.A. ${ }^{\text {, }}$, McGowan, S. ${ }^{\text {b }}$, Rose, N. L. ${ }^{\text {, }}$,

5 Panizzo, V. ${ }^{\text {b }}$, Yang, H. ${ }^{\text {d }}$, Vologina, E. e , Sturm, M. ${ }^{\text {f }}$, Shchetnikov, A.A. ${ }^{\text {e, g, h, i }}$

$7 \quad{ }^{\text {a }}$ Canada Centre for Inland Waters, Environment and Climate Change Canada, Burlington ON

8 L7S 1A1, Canada

9 b School of Geography, University of Nottingham, University Park, Nottingham NG7 2RD, United

10 Kingdom

11 c Department of Biology, University of Waterloo, 200 University Avenue West, Waterloo,

12 Ontario, N2L 3G1, Canada

13 d Environmental Change Research Centre, Department of Geography, Pearson Building, Gower

14 Street, University College London, London WC1E 6BT, United Kingdom

15 e Institute of Earth's Crust, Siberian Branch of the Russian Academy of Sciences, 128 ul.

16 Lermontov, Irkutsk, 664033, Russia

$17 \mathrm{f}$ Swiss Federal Institute of Aquatic Science and Technology EAWAG-ETH, 8600, Dubendorf,

18 Switzerland

19 g Irkutsk State University, 2 Chkalov St., Irkutsk, 664003, Russia

20 h Geological Institute, Russian Academy of Sciences, Pyzhevsky lane 7, 119017, Moscow, Russia

21 i Irkutsk Scientific Centre, Siberian Branch of the Russian Academy of Sciences, 134 ul, 22 Lermontov, Irkutsk, 664033, Russia

$23 *$ Corresponding authors e-mail: sarah.roberts2@canada.ca (S. Roberts) and 24 j24adams@uwaterloo.ca (J.Adams)

26 Abstract

27 Mercury (Hg) loading in Lake Baikal, a UNESCO world heritage site, is growing and poses a 28 serious health concern to the lake's ecosystem due to the ability of $\mathrm{Hg}$ to transform into a toxic 
29 form, known as methylmercury (MeHg). Monitoring of $\mathrm{Hg}$ into Lake Baikal is spatially and

30 temporally sparse, highlighting the need for insights into historic Hg loading. This study reports

31 measurements of $\mathrm{Hg}$ concentrations from water collected in August 2013 and 2014 from across

32 Lake Baikal and its main inflow, the Selenga River basin (Russia, Mongolia). We also report

33 historic $\mathrm{Hg}$ contamination using sediment cores taken from the south and north basins of Lake

34 Baikal, and a shallow lake in the Selenga Delta. Field measurements from August 2013 and 2014

35 show high Hg concentrations in the Selenga Delta and river waters, in comparison to pelagic lake

36 waters. Sediment cores from Lake Baikal show that $\mathrm{Hg}$ enrichment commenced first in the south

37 basin in the late- $19^{\text {th }}$ century, and then in the north basin in the mid- $20^{\text {th }}$ century. Hg flux was also

38 20-fold greater in the south basin compared to the north basin sediments. Hg enrichment was

39 greatest in the Selenga Delta shallow lake (Enrichment Ratio (ER) $=2.3$ in $1994 \mathrm{CE}$ ), with

40 enrichment occurring in the mid- to late- $20^{\text {th }}$ century. Local sources of $\mathrm{Hg}$ are predominantly from

41 gold mining along the Selenga River, which have been expanding over the last few decades. More

42 recently, another source is atmospheric deposition from industrial activity in Asia, due to rapid

43 economic growth across the region since the 1980s. As Hg can bioaccumulate and biomagnify

44 through trophic levels to Baikal's top consumer, the world's only truly freshwater seal (Pusa

45 sibirica), it is vital that $\mathrm{Hg}$ input at Lake Baikal and within its catchment is monitored and 46 controlled.

47 Keywords: Mercury, mining, atmospheric deposition, lake sediments

\section{1. Introduction}

50 Mercury $(\mathrm{Hg})$ is a global pollutant of concern and has both natural and anthropogenic sources.

51 Once emitted, most inorganic $\mathrm{Hg}$ can remain in the atmosphere for up to 12 months (Corbitt et al., 
52 2011) and can be transported across the world. Gaseous and particulate $\mathrm{Hg}$ emitted into the

53 atmosphere is transformed into $\mathrm{Hg}$ (II), which is then deposited onto the landscape via wet and dry

54 deposition (Bergan and Rodhe, 2001). Atmospherically emitted Hg will cycle between short-term

55 stores $(<10$ years) in the atmosphere, terrestrial environments, and surface ocean waters, before

56 being sequestered long-term into terrestrial soils and sediments, ocean margins and the deep ocean

57 (Amos et al., 2014). Within aquatic environments, methylating bacteria can transform $\mathrm{Hg}$ (II) into

58 a toxic organic form, known as methylmercury (MeHg). This organic form makes $\mathrm{Hg}$ especially

59 harmful within aquatic ecosystems as it can bioaccumulate and biomagnify in foodwebs. Due to

60 the toxicity of MeHg, the Minimata Convention was set up in 2017 to reduce the impact that human

61 activities have on $\mathrm{Hg}$ releases to the environment (UN Environment, 2017). Hg cycling in aquatic

62 environments may be affected by dissolved organic carbon (DOC), $\mathrm{pH}$, temperature, redox

63 conditions, sulfate concentrations and microbial activity, which control methylation

64 (transformation of $\mathrm{Hg}$ into $\mathrm{MeHg}$ ) and demethylation (transformation of $\mathrm{MeHg}$ into $\mathrm{Hg}$ ) processes

65 (Hintelmann et al., 1995; Kelly et al., 2003; French et al., 2014). Environmental changes associated

66 with warming (e.g. increased weathering, temperature, productivity and organic loadings) can also

67 affect $\mathrm{Hg}$ cycling, by stimulating methylation and inhibiting photodecomposition, due to

68 increasing primary productivity and DOC concentrations which reduce light penetration in the

69 water column (Hammerschmidt et al., 2006).

70 Lake Baikal is a UNESCO World Heritage Site and is internationally important for its high levels

71 of water purity and endemism (Fig. 1). Gold mining began in Lake Baikal's catchment with the

72 discovery of the Ildikan deposit in the mid-1800s (Maruev, 2018). Small-scale gold mining

73 operations use $\mathrm{Hg}$ to extract gold from ore in a process of amalgamation and distillation. The first

74 gold extraction processes using Hg started along the Kharaa River, in the basin of the Amur River 
75 in 1837 CE (common era), and in the basin of the Selenga River (Lake Baikal's primary inflow)

76 in 1841 CE (Misyurkeeva, 2009; Maruev, 2018). Between 1860-1890 CE 40\% of all gold in Russia

77 was mined in the Baikal region, with $\mathrm{Hg}$ used in the extraction before being disposed in rivers and

78 dispersed into the atmosphere (Maruev, 2018). Since the 1950s, the use of Hg in gold extraction

79 has stopped in the Russian region of the Baikal catchment, but continues in the Mongolian Selenga

80 River basin (Misyurkeeva, 2009). Over the last few decades, gold extraction along the Selenga

81 River has increased, with over 700 mines currently in operation in the Baikal catchment within

82 Mongolia (Brunello et al., 2004; Pietron et al., 2017), and the largest gold mining operation, the

83 Zaamar Goldfield, situated within the Mongolian Selenga River basin (Tumenbayer et al., 2000;

84 Chalov et al., 2015; Pietron et al., 2017). Recent studies report the Lake Baikal catchment and

85 Selenga River basin to be heavily polluted from these gold extraction activities (Brunello et al.,

86 2012; Thorslund et al., 2012; 2016; Brumbaugh et al., 2013; Chalov et al., 2015; Jarsjö et al., 2017;

87 Hampton et al., 2018).

88 Within the past decade, MeHg bioaccumulation has been observed in Baikal's pelagic foodweb

89 (Perrot et al., 2010; 2012; Ciesielski et al., 2016). High Hg concentrations have been reported in

90 fish from the Selenga River basin, which are above the recommended thresholds for human

91 consumption (Kaus et al., 2017), and in the water reservoir north of Irkutsk in the Baikal region

92 (Koval et al., 1999). Analyses of the livers and muscle of the Baikal Seal (Pusa sibirica), have also

93 shown Hg contamination within the lake's top consumer in the 1960s and 1970s, before declining

94 to present (2013 CE) in response to reduced atmospheric Hg emissions from Europe and Russia

95 (Ozersky et al., 2017).

96 Recent and current levels of $\mathrm{Hg}$ contamination at Lake Baikal are largely unknown due to sparse

97 records of $\mathrm{Hg}$ measurements and the lack of historical $\mathrm{Hg}$ loading records for the region. Within 
98 this study, we have undertaken the first $\mathrm{Hg}$ assessment for Lake Baikal in 20 years (Leermakers et

99 al., 1996), and aim to address the following research questions: 1) is the Selenga River basin a

100 major source of $\mathrm{Hg}$ into Lake Baikal, and (2) has there been $\mathrm{Hg}$ enrichment in the Selenga Delta

101 and Lake Baikal since the onset of gold mining and development in the region?

\section{2. Materials and Methods}

\section{$103 \quad$ 2.1. Study sites and field collection}

104 Lake Baikal can be divided into three main basins (south, central and north) with the central basin

105 separated from the south basin by the Buguldeika Ridge and the more than $20 \mathrm{~km}$ wide Selenga

106 River Delta. The Selenga River, which is approximately $943 \mathrm{~km}$ long (Nadmitov et al., 2015), is

107 the main tributary into Lake Baikal and contributes over $60 \%$ of annual flow into the lake. It

108 originates in the Khangai Mountains, northern Mongolia, and accounts for over $80 \%$ (over 447,000

$109 \mathrm{~km}^{2}$ ) of Baikal's catchment (Nadmitov et al., 2015). The majority of the Selenga River basin is

110 situated in Mongolia $\left(282,349 \mathrm{~km}^{2}\right)$ rather than Russia $\left(148,060 \mathrm{~km}^{2}\right)$, with the basin covering

111 almost 20\% of the total land area in Mongolia (Nadmitov et al., 2015). The Selenga River branches

112 into the Selenga Delta, the world's largest freshwater inland delta (Logachev, 2003), and a Ramsar-

113 designated floodplain wetland, which is internationally important for high rates of biodiversity and

114 migratory bird habitat (Scholz and Hutchinson, 2000).

115 The region around Lake Baikal became one of the most highly $\mathrm{Hg}$ polluted regions in Siberia,

116 following industrialization of the catchment between the 1950s and 1990s (Koval et al., 1999).

117 The largest cities and main industrial districts in Mongolia (Ulaanbaatar, Erdenet and Darkhan)

118 are situated along the main tributaries of the Selenga River, namely the Tuul, Orkhon and Kharaa

119 rivers, respectively. In Russia, Ulan Ude and Selenginskii are situated along the Selenga River

120 (Kasimov et al., 2017). Other major polluting cities and towns within Lake Baikal's catchment and 
121 airshed include Irkutsk, Gusinoozersk and Severobaykalsk. Notorious industrial Hg emitters in the

122 region include metallurgical plants which produce $\mathrm{Hg}$ directly, chemical and electrical plants,

123 where $\mathrm{Hg}$ is an element in the manufacturing process, and coal and oil fired thermal electric power

124 plants, where Hg is recovered (Vasiliev et al., 1998). Chemical industries are prominent within the

125 Irkutsk-Cheremkhovo industrial zone and are a major concern for Hg pollution (Koval et al.,

126 1999). Other major regional Hg pollution sources include the Gusinoozersk State Regional Power

127 Plant (a coal-fired power plant), and the Selenginsk Pulp and Cardboard Mill within the Selenga

128 River basin, which began operating in $1974 \mathrm{CE}$ and continued as an open system until $1990 \mathrm{CE}$

129 (Pisarksy et al., 2005; Nikanorov et al., 2012; Nomokonova et al., 2013). Industrial activity around

130 the shores of Lake Baikal began in the $20^{\text {th }}$ century, and the Baikal Pulp and Paper Mill (BPPM),

131 which was in operation between 1966 to 2013, was a suggested point source of $\mathrm{Hg}$ (Brunello et

132 al., 2004).

133 Five sites were selected within Lake Baikal for surface water sampling to represent the main

134 basins, including the south basin (BAIK13-8), the shallow waters off the Selenga Delta (BAIK13-

135 10), the central basin (BAIK13-12), within Maloe More Bay off the central basin (BAIK13-14),

136 and the Upper Angara River in the north basin (BAIK13-19) (Fig. 1; Table S2). Maloe More Bay

137 is a vulnerable region of Lake Baikal, currently affected more than deeper water sites by

138 anthropogenic influence (Timoshkin et al., 2016). Additionally, water samples at five sites from

139 the Selenga Delta branches (SDB01 to SDB05), fourteen sites from Selenga Delta shallow water

140 bodies (SLNG01, SLNG03-SLNG15), three sites from the Selenga River (B13-8-11, B13-8-20

141 and B13-8-26), and one shallow lake (Black Lake; BRYT) within the upstream section of the

142 Siberian Selenga River basin were analysed for Hg (Fig. 1; Table S2). 
144 Prior to water sample collection, bottles (120 mL PFA Savillex) were soaked in 5\% Decon 90 145 solution for 24 hours, followed by multiple rinses of deionized water and then soaked in $1 \mathrm{M}$ super 146 pure $\mathrm{HCl}$ for another 24 hours. This was then followed by extensive rinsing in deionized water and 147 double-bagging after drying. Unfiltered samples were acidified with $1.25 \mathrm{~mL}$ analytical grade $\mathrm{HCl}$ 148 (Romil Superpure $10 \mathrm{M})$ and stored at $4^{\circ} \mathrm{C}$ prior to analyses. Short sediment cores $(<65 \mathrm{~cm})$ were 149 collected using an UWITEC gravity corer (UWITEC Ltd., Austria) fitted with a $6.3 \mathrm{~cm}$ internal 150 diameter Perspex ${ }^{\circledR}$ acrylic tube (UWITEC Ltd.) in August 2013 from BAIK13-10 (core: BAIK13151 10A, water depth $=66 \mathrm{~m}$ ), BAIK13-19 (core: BAIK13-19B, water depth $=460 \mathrm{~m}$ ), and in March 1522014 from SLNG04 (core: SLNG04-C, water depth = 1.3 m) (Fig. 1; Table S1; S2). The sediment 153 cores were extruded in the field at $0.2 \mathrm{~cm}$ (BAIK13-10A and 19B) or $0.5 \mathrm{~cm}$ (SLNG04-C) intervals 154 using a vertical extruder. Extruded sediment samples were stored in Whirlpak ${ }^{\circledR}$ bags, shipped to 155 University College London (UCL), London, UK and University of Nottingham, UK, and stored at $156-20^{\circ} \mathrm{C}$ until processing. Radiometric chronologies for sediment core BAIK13-10A and BAIK13157 19B have been previously published in Roberts et al. (2018), and for SLNG04-C in Adams et al. 158 (2018) (Fig. S1). These ${ }^{210} \mathrm{~Pb}$ chronologies were constructed using the constant rate of supply 159 (CRS) dating model (Appleby, 2001), and independently verified using ${ }^{137} \mathrm{Cs}$. 


\subsection{Laboratory analysis of $\mathrm{Hg}$ concentrations in water samples}

$163 \mathrm{Hg}$ in water samples was analysed at the Environmental Mercury Analytical Facility at UCL, UK.

$1640.25 \mathrm{~mL}$ concentrated $\mathrm{HCl}$ (Romil, pure grade) and $0.25 \mathrm{~mL} 0.1 \mathrm{~N} \mathrm{BrO}^{3-} / \mathrm{Br}^{-}$(purified) was added

165 to each $45 \mathrm{~mL}$ water sample, which was then sealed for 30 minutes, had $15 \mu \mathrm{g} / \mathrm{L} 12 \% \mathrm{NH}_{2} \mathrm{OH}-$

$166 \mathrm{HCl}$ added, and diluted to $50 \mathrm{~mL}$. Hg concentrations were analysed using gold trap cold vapour-

167 atomic fluorescence spectrometry (CV-AFS) following reduction with $\mathrm{SnCl}_{2}$ (US EPA, 2002).

168 Detection limit is $0.4 \mathrm{ng} / \mathrm{L}$; measurement errors for the $\mathrm{Hg}$ concentrations of less than $4 \mathrm{ng} / \mathrm{L}$ were

$1690.4 \mathrm{ng} / \mathrm{g}$, and 10\% for concentrations greater than $4 \mathrm{ng} / \mathrm{L}$. Standard solutions and quality control

170 blanks were measured after every three samples to monitor measurement stability.

\section{2.3. Laboratory analysis of $\mathbf{H g}$ concentrations in sediments}

172 Sediment samples were freeze-dried using a Thermo Modulyo D freeze-drier in which samples

173 were kept for several days at temperatures of $-40^{\circ} \mathrm{C}$ until the pressure was $<100$ mTorr. Freeze-

174 dried sediment samples were analysed at a temporal resolution of 5 - 20 years for BAIK13-10A

175 and BAIK13-19B. For SLNG04, samples were analysed through the core at a temporal resolution

176 of approximately 15 years. $\mathrm{Hg}$ analyses on sediment samples followed procedures in Yang et al.

177 (2010a). For each sample, approximately $0.2 \mathrm{~g}$ fine powdered freeze-dried sediment, was digested

178 with $8 \mathrm{~mL}$ of a 1:3 mixture of $\mathrm{HNO}_{3}$ and $\mathrm{HCl}$ (aqua regia) at $100^{\circ} \mathrm{C}$ on a hotplate for 2 hours in

179 rigorously acid-leached $50 \mathrm{~mL}$ Teflon digestion tubes. Following digestion, samples were diluted

180 to $50 \mathrm{~mL}$ with deionized water, capped and mixed. Digested solutions were then analysed for $\mathrm{Hg}$

181 using cold vapour-atomic fluorescence spectrometry (CV-AFS), following reduction with $\mathrm{SnCl}_{2}$.

182 Standard reference material (GBW07305; certified $\mathrm{Hg}$ value of $100 \pm 10.0 \mathrm{ng} / \mathrm{g}$ and measured

183 mean value is $104 \mathrm{ng} / \mathrm{g}$, with $\mathrm{RSD}=4.3 \mathrm{ng} / \mathrm{g}(\mathrm{n}=3))$, and sample blanks were digested with every

18420 samples. 


\subsection{Hg enrichment and total fluxes}

186 To examine trends in $\mathrm{Hg}$ loading over time, total $\mathrm{Hg}$ fluxes were calculated using the

187 radiometrically-derived sedimentation rates (Fig. S1). Standard enrichment factors could not be

188 calculated as lithogenic element data (for example Al, Li and Ti; Ribeiro et al., 2018) were not

189 available for the cores. Instead, $\mathrm{Hg}$ enrichment ratios (ER) were calculated by normalising $\mathrm{Hg}$

190 concentrations in sediments deposited after $1850 \mathrm{CE}$, as determined from the age-depth model, by

191 the natural baseline (mean $\mathrm{Hg}$ concentrations prior to $1850 \mathrm{CE})(\mathrm{BAIK} 13-10 \mathrm{~A}$ baseline mean $=$

$19230.4 \pm 6.4 \mathrm{ng} / \mathrm{g} ; \mathrm{BAIK} 13-19 \mathrm{~B}=35.5 \pm 6.6 \mathrm{ng} / \mathrm{g} ; \mathrm{SLNG} 04-\mathrm{C}=22.6 \pm 1.2 \mathrm{ng} / \mathrm{g})$. The calculated

193 ER therefore represent a comparative ratio of background vs post-1850 $\mathrm{Hg}$ concentrations (Yang

194 et al., 2010b). A baseline date of $1850 \mathrm{CE}$ was chosen to take into account global atmospheric

195 contamination from industrialisation, despite the main regional development and expansion in the

196 Lake Baikal catchment region beginning in the 1900s (Brunello et al., 2004). An ER of $>1.4$

197 demonstrates that post-1850 Hg concentrations are in exceedance of baseline by $2 \mathrm{SD}$, suggesting

198 post-1850 anthropogenic pollution. To examine trends in $\mathrm{Hg}$ loading, constrained cluster and

199 broken stick analyses were conducted on $\mathrm{Hg}$ concentration profiles from the three sediment cores,

200 to determine points of significant change, using the rioja package in $\mathrm{R}$ (version 3.5.2; R Core

201 Team, 2018) (Juggins, 2017).

\section{3. Results \& Discussion}

\section{3.1. Spatial patterns and modern Hg sources}

204 Water Hg concentrations ranged between 5.3 and $10.1 \mathrm{ng} / \mathrm{L}$ in the Selenga Delta shallow water

205 bodies and between 0.3 and $5.5 \mathrm{ng} / \mathrm{L}$ in the Selenga Delta branches with a decreasing trend from

206 the Selenga River to the mouth of the delta (Fig. 1). Along the Selenga River, Hg concentrations

207 ranged from 6.0 to $8.1 \mathrm{ng} / \mathrm{L}$ with highest values at the furthest upstream locations near the town of 
208 Ust-Kyakhta (B13-8-26) (Fig. 1). Black Lake (BRYT), within the Selenga River basin, had the

209 lowest Hg concentration of the shallow lakes, at $4.2 \mathrm{ng} / \mathrm{L}$ (Fig. 1). In the waters of Lake Baikal,

$210 \mathrm{Hg}$ concentrations reached $3.2 \mathrm{ng} / \mathrm{L}$ at the one site (BAIK13-19) in the north basin, near the Upper

211 Angara and ranged from below the limit of detection to $1.6 \mathrm{ng} / \mathrm{L}$ in the south and central basin lake

212 waters (Fig. 1), while near the Selenga Delta at BAIK13-10 the $\mathrm{Hg}$ concentration was $1.6 \mathrm{ng} / \mathrm{L}$.

213 The spatial gradient from higher $\mathrm{Hg}$ concentrations in the upstream Selenga River to low

214 concentrations in Lake Baikal is expected due to the mining activity along the Selenga River, and

215 industrial activities in the cities of Ulan Ude and Selenginsk (Fig. 1). With the exception of

216 SLNG07, concentrations in the Selenga Delta shallow lakes are consistently higher than in the

217 Selenga Delta branches, and are higher than concentrations found in Lake Baikal. Mercury

218 concentrations are at their highest and most variable in lakes on the east side of the Delta but are

219 similar amongst lakes on the west side (Fig. 1). Single spot samples raise uncertainty regarding

220 their spatial and temporal representativity and should be interpreted with caution. Nevertheless,

221 the water $\mathrm{Hg}$ concentrations are likely indicating that the lakes of the Selenga Delta are acting as

222 retention ponds for $\mathrm{Hg}$ contamination within the Selenga River basin and preventing it from

223 entering Lake Baikal. River deltas are known hotspots for geochemical retention and

224 transformations, which may be controlled by seasonal and hydrological factors, including sediment

225 load and flow (Lychagin et al., 2015; Chalov et al., 2016). As most of the Hg in rivers is particle-

226 bound, much of it will tend to deposit in the smaller branches and shallow water bodies of the

227 Selenga Delta, as flow decreases (Amos et al., 2014). However, the fraction of the suspended

228 particle load in rivers that is buried is highly variable depending on freshwater discharge rates and

229 the physical characteristics of different deltas (Amos et al., 2014). 
230 Lake Baikal surface water Hg concentrations in August 2013 (mean $1.52 \pm 1.14 \mathrm{ng} / \mathrm{L}$ ) were higher

231 than previously published values of $0.14-0.77 \mathrm{ng} / \mathrm{L}$ in June $1992-1993$ (Meuleman et al., 1995;

232 Baeyens et al., 2002). The slightly elevated $\mathrm{Hg}$ concentration observed in the north basin at

233 BAIK13-19 (3.2 ng/L) are consistent with the suggestion that there is a nearby riverine source,

234 however, there is no supporting evidence that the Upper Angara River is impacting the water Hg

235 concentrations, through contamination from industry in the north basin catchment. The largest

236 town in this area is Severobaykalsk, and the largest village settlement previously reported is

237 Nizhneangarsk (Rose et al., 1998). The Baikal-Amur railroad also travels through this region. The

238 main $\mathrm{Hg}$ sources in Severobaykalsk are from fossil-fuel combustion facilities, waste incineration

239 processes and chemical or electrical industries. These sources have been demonstrated in past

240 studies to contribute to the higher than expected spheroidal carbonaceous particle (SCP)

241 concentrations in the north basin of Lake Baikal (BAIK28; Rose et al., 1998). Alongside

242 anthropogenic sources, another possible source of $\mathrm{Hg}$ into Lake Baikal is from the hydrothermal

243 vents at the bottom of the lake, which form as a result of the active tectonic rift boundary (Crane

244 et al., 1991; Kipfer et al., 1996). This geothermal activity mainly occurs in the north basin of Lake

245 Baikal and releases Hg into the sediments and water column via the hydrothermal waters which

246 are enriched in metals (Crane et al., 1991; Kipfer et al., 1996). Isotope ratios of $\mathrm{Hg}$ can be used to

247 distinguish between sources; however, it has been suggested that hydrothermal discharge along

248 fault lines at the bottom of Lake Baikal causes only a minor impact on the lake water chemistry

249 (Granina et al., 2007).

\section{3.2. Historic trends of sediment Hg contamination}

251 Hierarchical cluster analysis indicates that sedimentary Hg concentrations at BAIK13-10 increase 252 significantly at c. $1840 \mathrm{CE}$ from $39 \mathrm{ng} / \mathrm{g}$ to $48 \mathrm{ng} / \mathrm{g}$. At BAIK13-19, sedimentary Hg concentrations 
253 increase towards the top of the core, with concentrations increasing significantly after $1920 \mathrm{CE}$

254 and remaining elevated to the surface (Fig. 2). While only two samples comprise the post-1940s

255 timeframe at BAIK13-19, they display similar concentrations of 53 and $51 \mathrm{ng} / \mathrm{g}$. Hg concentrations

256 at SLNG04 showed a gradually increasing trend beginning c. $1950 \mathrm{CE}$, with a significant increase

257 in $\mathrm{Hg}$ concentration (c. $1960 \mathrm{CE}$ ) that continue to increase until a maximum concentration of 56

$258 \mathrm{ng} / \mathrm{g}$ at c. $1990 \mathrm{CE}$. Sediment concentrations at SLNG04 then declined slightly after $1990 \mathrm{CE}$ but

259 have remained relatively steady during the past two decades (Fig. 2). Sediment Hg concentrations

260 in Lake Baikal and the Selenga Delta are comparable with previous studies from Lake Baikal,

261 which reported values between c. $40-70 \mathrm{ng} / \mathrm{g}$ over a $16 \mathrm{~cm}$ sediment core depth, collected in 1990

262 CE (with no published sediment core chronology) (Leermakers et al., 1996).

263 Maximum and contemporary Hg concentrations show an approximate doubling of concentration

264 after $1945 \mathrm{CE}$ across the sampled region, with recent concentrations close to $50 \mathrm{ng} / \mathrm{g}$ at all sites.

265 Sediments from BAIK13-10 show Hg enrichment, with Enrichment Ratios (ERs) ranging between

2661.6 and 1.7 from $1910 \mathrm{CE}$ to $2013 \mathrm{CE}$ (Fig. 2). Similarly, the BAIK13-19 sediment core from

267 nearby the Upper Angara River in the north basin shows Hg enrichment in the upper sediments,

268 with ERs ranging between 1.2 and 1.5 from $1880 \mathrm{CE}$ to $1960 \mathrm{CE}$ (Fig. 2). Sediments from SLNG04

269 indicate little enrichment of $\mathrm{Hg}$ (ER c. 1.0) until the mid-20 ${ }^{\text {th }}$ century when $\mathrm{Hg}$ enrichment quickly

270 increased and was consistently $>1.4$ between c. 1960 CE and 2013 CE (Fig. 2). Hg enrichment

271 peaks at c. $1990 \mathrm{CE}$ at SLNG04 with an ER of 2.3, but declined to 1.9 by $2013 \mathrm{CE}$.

272 Total fluxes of $\mathrm{Hg}$ show higher values post- $1850 \mathrm{CE}$, compared to pre-1850 CE, in both the south

273 basin (BAIK13-10) and north basin (BAIK13-19) sediment cores from Lake Baikal. However,

274 post- $1850 \mathrm{CE} \mathrm{Hg}$ flux was 20 -fold greater in the south basin compared to the north basin sediment

275 core (Fig. 2). In BAIK13-10, Hg fluxes ranged from $0.26 \mathrm{ng} / \mathrm{cm}^{2} / \mathrm{yr}$ in $1910 \mathrm{CE}$ to $6.32 \mathrm{ng} / \mathrm{cm}^{2} / \mathrm{yr}$ 
276 in $2013 \mathrm{CE}$ (Fig. 2), whereas in the north basin (BAIK13-19) a smaller range in $\mathrm{Hg}$ flux is recorded

277 in the sediments over the post- $1850 \mathrm{CE}$ period (from $0.38 \mathrm{ng} / \mathrm{cm}^{2} / \mathrm{yr}$ in $1880 \mathrm{CE}$ to $0.43 \mathrm{ng} / \mathrm{cm}^{2} / \mathrm{yr}$

278 in 2013 CE (Fig. 2)). Due to limitations of radiometric dating, SLNG04 Hg flux can only be 279 calculated from the mid-20 $0^{\text {th }}$ century, but fluxes show a distinct increase between c. $1945 \mathrm{CE}$ and 280 c. $1995 \mathrm{CE}$, from 2.3 to $11.0 \mathrm{ng} / \mathrm{cm}^{2} / \mathrm{yr}$. Since c. $1995 \mathrm{CE}, \mathrm{Hg}$ flux at SLNG04 has declined slightly 281 to $8.1 \mathrm{ng} / \mathrm{cm}^{2} / \mathrm{yr}$ (Fig. 2).

282 Both modern water samples and sedimentary records from Lake Baikal show that lakes in the 283 Selenga Delta appear to retain Hg. In the sedimentary records this retention effect is apparent as 284 Hg enrichment levels in Selenga Delta sediment core (SLNG04: mean post-1850 $=6.47 \pm 3.01$ $285 \mathrm{ng} / \mathrm{cm}^{2} / \mathrm{yr}$ ) reach over 2-fold greater than baseline concentrations, which is a slightly higher range 286 than in the south basin sediments (BAIK13-10: mean post-1850 $=2.85 \pm 2.27 \mathrm{ng} / \mathrm{cm}^{2} / \mathrm{yr}$ ) in Lake 287 Baikal close to the Selenga Delta system (Fig. 1), and 18-fold higher compared to in the north 288 basin sediment core (BAIK13-19: mean post-1850 $=0.35 \pm 0.09 \mathrm{ng} / \mathrm{cm}^{2} / \mathrm{yr}$ ) (Fig. 2). The higher 289 sedimentary Hg fluxes in these Selenga Delta lakes, compared to Lake Baikal, is also expected 290 due to their closer proximity to the sources of Hg pollution within the Selenga River area. It is 291 important to note, however, that these enrichment levels are similar to those found in remote lakes 292 in Uganda, North America, Europe and Arctic Alaska, where Hg concentrations were up to 3-fold 293 higher than those in the pre-industrial period (Swain et al., 1992; Fitzgerald et al., 2005; Engstrom 294 et al., 2007; Yang et al, 2010a), which indicates that Hg loading at Lake Baikal is not greater than 295 the global background $\mathrm{Hg}$ enrichment levels. These enrichment levels in remote lakes (Swain et 296 al., 1992; Fitzgerald et al., 2005; Engstrom et al., 2007; Yang et al, 2010a) relate to atmospheric 297 deposition sources and not riverine drainage of industrial areas. Furthermore, Lake Baikal 298 sediment records covering the last 6 million years show naturally elevated Hg concentrations in 
299 the sediments during warmer climatic conditions (average $\mathrm{Hg}$ concentrations of $46 \pm 11 \mathrm{ng} / \mathrm{g}$

300 during warm periods and $27 \pm 12 \mathrm{ng} / \mathrm{g}$ during cold periods), and anomalously high peaks in $\mathrm{Hg}$

301 concentrations (between $210-420 \mathrm{ng} / \mathrm{g}$ ) during volcanic events in the Baikal area (Gelety et al.,

302 2007). By comparison, $\mathrm{Hg}$ concentrations from BAIK13-10 and BAIK13-19 are only slightly

303 higher than the average Hg concentration during warmer periods (Gelety et al., 2007).

$304 \mathrm{Hg}$ enrichment levels are lower in the north basin (average post-1850 ER for BAIK13-19 $=1.3 \pm$

3050.16 ) than the south basin (average post-1850 ER for BAIK13-10 $=1.6 \pm 0.05$ ) and Selenga Delta

306 lake (average post-1850 ER for SLNG04 $=1.6 \pm 0.42$ ). Moreover, ER results suggest an

307 enrichment of north basin (BAIK13-19) sediments after $1940 \mathrm{CE}$, whereas the south basin

308 (BAIK13-10) site near the Selenga Delta experienced enrichment much earlier at around 1910 CE.

309 Such temporal differences in the onset and overall magnitude of $\mathrm{Hg}$ enrichment between north and

310 south basins, and the Selenga Delta, suggest local scale sources of Hg contamination. Hg

311 enrichment of the south basin sediments in the early 1900s suggests the contribution of

312 contamination from local sources as a result of industrialization in the Lake Baikal catchment and

313 the adjacent areas drained by the Angara and Lena rivers. The mid-20 $0^{\text {th }}$ century onset of $\mathrm{Hg}$

314 enrichment in the north basin is perhaps attributed to the development of the major town on the

315 north basin shores, Severobaykalsk, which was only founded in the 1970s and with the completion

316 of the Baikal-Amur Mainline railway.

317 All three sediment cores indicate increases in $\mathrm{Hg}$ flux in Lake Baikal post-1850 CE, but the 318 subsurface peak in SLNG04 Hg flux indicates a possible mid-1990s peak in the delivery of Hg to

319 the Selenga River/Lake Baikal system from both local and long-range sources. Adams et al. (2018)

320 recorded similar timing in decline of polycyclic aromatic hydrocarbons (PAHs), polychlorinated

321 biphenyls (PCBs), and dichlorodiphenyltrichloroethane (DDT) fluxes to SLNG04, while Rose et 
322 al. (1998) recorded evidence of SCP concentration declines in Lake Baikal sediments after 1990,

323 likely indicating a regional decline in industrial coal and oil combustion in southeast Siberia. The

324 timing of this observed decline in anthropogenic contamination in the Lake Baikal region ties in

325 with the economic recession in the early 1990s following the collapse of the former Soviet Union

326 (Khanin, 2003; Adams et al. 2018). However, the decline in Hg flux at SLNG04 is not large and

327 remains elevated relative to pre- c. 1950 CE levels. Differences in Hg flux between Lake Baikal

328 and the Selenga Delta are also likely due to the high affinity of $\mathrm{Hg}$ for organic matter; $\mathrm{Hg}$ binds to

329 DOC and the Selenga Delta lakes receive a higher input of catchment derived DOC than the pelagic

330 regions of Lake Baikal (Yoshioka et al., 2002). Thus, the higher input of DOC bound Hg into the

331 Selenga Delta lakes could be a contributing factor to the elevated levels of Hg enrichment seen in

332 these lakes in comparison to Lake Baikal. Alternatively, the Selenga Delta might be receiving

333 greater impacts from local sources than Lake Baikal, as a result of more sediments being deposited

334 in the SLNG04 location, and therefore SLNG04 is actually more highly contaminated by $\mathrm{Hg}$

335 inputs. The large differences in water column depths between the coring sites may also effect $\mathrm{Hg}$

336 fluxes, as within deeper water sites at BAIK13-10 (66 m) and BAIK13-19 (460 m) more particulate

337 matter decomposition will occur within the water column, than in the shallow Selenga Delta site,

338 SLNG04 (1.3 m). In deeper waters, more particulate-bound $\mathrm{Hg}$ will be released during particle-

339 scavenged remineralization down the water column, as well as photo-reductive and photo-induced

340 micro-biological processes, resulting in the evasion of $\mathrm{Hg}$ fluxes reaching deeper water sediments

341 (O’Driscoll et al., 2003).

342 In summary, sedimentary profiles in the south and north basin of Lake Baikal are likely to reflect

343 of both local sources and long-range atmospheric deposition of $\mathrm{Hg}$, however the retention of $\mathrm{Hg}$

344 in the Selenga Delta reduces inputs to Lake Baikal from the Selenga River. As Hg can remain 
345 within the atmosphere for up to a year, an important anthropogenic source of Hg to Lake Baikal

346 and its catchment area is likely to be atmospherically transported $\mathrm{Hg}$ from industrial centres, from

347 other urban areas in Russia and across the globe (Gelety et al., 2007; UNEP Global mercury

348 assessment, 2013). Air pollution controls and mitigation efforts in North America and Europe have

349 helped to reduce their $\mathrm{Hg}$ emissions from industrial activity. However, in Asia (mainly China and

350 India), $\mathrm{Hg}$ emissions have been rising since the 1990s due to the marked economic expansion

351 (Pacyna et al., 2016; Sundseth et al., 2017). Declines in Hg ER and flux at SLNG04 since the late-

352 1900s indicates that long-range transport of $\mathrm{Hg}$ from elsewhere in Asia is likely to be an important

353 contributor to the enrichment at Lake Baikal; lake sediment cores from remote regions in China

354 show a marked increase in China's metal air pollution from 1990 CE (Wan et al., 2019) continuing

355 to present day (Yang et al., 2010b; UNEP Global mercury Assessment, 2013).

\section{$356 \quad 3.3$ Implications for Lake Baikal}

357 The 2013/2014 surveys of water Hg concentrations across Lake Baikal and the Selenga River basin

358 show elevated levels of $\mathrm{Hg}$ in the Selenga River waters, in comparison to Lake Baikal waters, most

359 likely linked to gold mining and location of industrial centres (Brunello et al., 2004; Thorslund et

360 al., 2012; 2016; Brumbaugh et al., 2013; Chalov et al., 2015; Jarsjö et al., 2017). However,

361 although the Selenga Delta reduces the extent of Hg pollution entering the south and central basins

362 of Lake Baikal, the current state of the environment in Lake Baikal's catchment gives cause for

363 concern with respect to future contamination by $\mathrm{Hg}$.

364 For example, re-emission of legacy $\mathrm{Hg}$ stores has become another important source of $\mathrm{Hg}$ pollution

365 to the landscape, which can be released via soil erosion and permafrost thaw (Yang, 2015).

366 Modelling of current $\mathrm{Hg}$ reservoirs by Amos et al. (2013) indicated that up to $60 \%$ of present-day 
367 atmospheric deposition of $\mathrm{Hg}$ is legacy-derived, re-emitted from surface reservoirs. Hydro-

368 climatic modelling studies for the Selenga River basin predict an increase in temperatures,

369 precipitation and run off between 2010 - 2099 under a high greenhouse gas emission scenario

370 (Törnqvist et al., 2014), which may lead to shifts in $\mathrm{Hg}$ loading as a result of altered hydrology

371 and basin-scale permafrost degradation (Zhoa et al., 2010; Törnqvist et al., 2014). Legacy Hg input

372 into Lake Baikal and the Selenga River basin is likely to increase with regional climate warming,

373 as permafrost underlays a large proportion of the catchment area (Hampton et al., 2008; Moore et

374 al., 2009) and catchment loading of $\mathrm{Hg}$ from the subsequent increased erosion of catchment soils

375 (Yang, 2015). In western Europe, changes to the climate system in recent years have also led to

376 increased storm events, causing further increased instability of catchment soils, increasing the

377 mobility of particulate-bound $\mathrm{Hg}$ across the terrestrial landscape (Yang and Smyntek, 2014). Thus,

$378 \mathrm{Hg}$ which has previously been deposited and stored within the lake catchment can also act as a

379 source of anthropogenic Hg to the lake system (Yang et al., 2002; Rose et al., 2012). Hg pollution

380 in Lake Baikal and the Selenga River basin area could therefore be a result of the continuing $\mathrm{Hg}$

381 use in gold extraction processes in Mongolia, plus historical legacy of past $\mathrm{Hg}$ used in the region,

382 including in Russian gold mining prior to $1950 \mathrm{CE}$ and industrial practices, as well as long-range

383 transport of atmospheric $\mathrm{Hg}$ from regional and international industrial centres, from metal

384 smelters, chemical and electrical industries, coal combustion facilities and waste incineration 385 plants.

386 Lake Baikal is increasingly facing pressures from shoreline anthropogenic nutrient pollution from 387 inadequate sewage treatment (Timoshkin et al., 2016), as well as pressures from recent 388 atmospheric warming since the 1950s which has been driving limnological and ecosystem changes 389 (Hampton et al., 2008; 2014; 2015; Moore et al., 2009; Izmest'eva et al., 2016; Silow et al., 2016; 
390 Roberts et al., 2018). These pressures, combined with the continued inputs of $\mathrm{Hg}$ from a variety

391 of sources, put the Lake Baikal ecosystem at risk from $\mathrm{Hg}$ inputs into the future. Efforts need to

392 be focussed on minimising Hg pollution to Lake Baikal and its catchment area, primarily by

393 eliminating the current use of $\mathrm{Hg}$ in the extraction process of small-scale gold mining operations

394 in Mongolia. Furthermore, global efforts, in accordance with the Minimata Convention need to

395 continue, to reduce industrial release of $\mathrm{Hg}$ emissions into the atmosphere, which is likely a sizable

396 contribution of contemporary Hg to Lake Baikal. Additionally, Hg levels need to be monitored on

397 the freshwater ecosystems of the Selenga Delta itself, as it is an important Ramsar site for

398 continental Eurasia, and demonstrates higher levels of $\mathrm{Hg}$ within the Lake Baikal catchment.

\section{5. Conclusions}

400 Mercury measurements from 2013/2014 demonstrate that the Selenga River is a major source of 401 anthropogenic Hg contamination into the Selenga Delta region and Lake Baikal, as a result of the 402 variety of sources of $\mathrm{Hg}$ within the Selenga River basin, including chemical (mainly the 403 manufacturing of chlorine) and electrical plants where $\mathrm{Hg}$ is an element in the manufacturing 404 process, metallurgical plants which produce $\mathrm{Hg}$ directly, coal and oil fired electric power plants, 405 and current gold mining activity within the Mongolian Selenga River basin. The low Hg 406 concentrations within Lake Baikal waters could be attributed to retention within the Selenga Delta 407 system, which contains higher water $\mathrm{Hg}$ concentrations, and a result of dilution by the large volume 408 of Lake Baikal. The highest water concentrations within Lake Baikal are seen at a north basin site 409 near the Upper Angara River. Moreover, spatiotemporal differences in the timing of $\mathrm{Hg}$ 410 enrichment in Lake Baikal and Selenga Delta sediments likely highlight key influences of local 411 and regional sources of $\mathrm{Hg}$ to Lake Baikal during the $19^{\text {th }}$ and $20^{\text {th }}$ centuries. Recent moderate 412 declines in ERs and fluxes may reflect declining local sources of $\mathrm{Hg}$ within the catchment. 
413 However, as concentrations currently remain elevated above background levels in all sediment

414 cores, long-range atmospheric sources likely continue to be a key contributor of Hg pollution in

415 Lake Baikal. Moreover, Hg concentrations measured in the sediments are similar to measurements

416 taken in the 1990s (Leermakers et al., 1996) and over warm climatic periods (Gelety et al., 2007).

417 Thus, with the projected hydro-climatic changes in the region from previous modelling studies,

418 there is a necessity to continue monitoring of $\mathrm{Hg}$ contamination for the protection of Lake Baikal

419 and the Selenga catchment, to reduce Hg pollution of this unique aquatic ecosystem and the

420 deterioration of a globally important freshwater resource.

421 With rising unregulated mining activity along the Selenga River, it is vital to monitor $\mathrm{Hg}$ pollution

422 across the Baikal catchment, especially as MeHg has already been found to bioaccumulate within

423 Lake Baikal's pelagic foodweb (Ciesielski et al., 2016). Furthermore, recent and future climate

424 warming is likely to increase the transfer of different forms of $\mathrm{Hg}$, such as $\mathrm{Hg}$ bound DOC across

425 the terrestrial landscape, from thawing permafrost and soil erosion (Zhoa et al., 2010; Rose et al.,

426 2012; Törnqvist et al., 2014) and greater fluvial inflows into connected rivers. These climate driven

427 processes might increase the Hg loading within the Selenga River basin, and ultimately into pelagic

428 Lake Baikal and its foodweb.

\section{6. Acknowledgements}

430 This work was supported by the Natural Environment Research Council (grants NE/J00829X/1,

$431 \mathrm{NE} / \mathrm{J010227/1}$, and NE/J007765/1), (NERC) Standard Grants, as well as RGS, QRA and UCL

432 Graduate School funds, RFBR (grant 18-05-00215), RSF (grant 19-17-00216), Government of the

433 Russian Federation (grant 075-15-2019-866), Integration Project SB RAS (grant 0341-2017-

434 0001). The authors are indebted to Nikolaj M. Budnev (Head of Applied Physics-Irkutsk State

435 University), the captain and crew of the Geolog research boat, and Dmitry Gladkochub (Director 
436 of IEC) in facilitating and organizing 2013 fieldwork. Thank you as well to D. White and I. Filinov

437 for 2014 fieldwork assistance. We also thank Miles Irving at UCL Department of Geography for

438 help with producing the map figure in this manuscript.

\section{References}

Adams, J.K., Martins, C.C., Rose, N.L., Shchetnikov, A.A., Mackay, A.W. (2018). 'Lake sediment records of persistent organic pollutants and polycyclic aromatic hydrocarbons in

443 Southern Siberia mirror the changing fortunes of the Russian economy over the past 70 years.'

444 Environmental Pollution, 242, 528-538.

Appleby, P.G. (2001). Chronostratigraphic techniques in recent sediments. In: Last, W.M., Smol, J.P. (Eds.), Tracking Environmental Change Using Lake Sediments, Volume 1: Basin Analysis, 448 Coring, and Chronological Techniques. Kluwer Academic Publishers, Dordrecht, pp. 171-203.

Amos, H.M., Jacob, D.J., Streets, D.G., Sunderland, E.M. (2013). 'Legacy impacts of all-time anthropogenic emissions on the global mercury cycle.' Global Biogeochemical Cycles, 27, 410421.

Amos, H.M., Jacob, D.J., Kocman, D., Horowitz, H.M., Zhang, Y., Dutkiewicz, S., Horvat,

M., Corbitt, E.S., Krabbenhoft, D.P. (2014). 'Global biogeochemical implications of mercury discharges from rivers and sediment burial.' Environment Science \& Technology, 48, 9514-9522.

Baeyens, W., Dehandschutter, B., Leermakers, M., Bobrov, V.A., Hus, R., Baeyens-Volant,

463 Bergan, T., Rodhe, H. (2001). 'Oxidation of elemental mercury in the atmosphere: constraints 464 imposed by global scale modelling.' Journal of Atmospheric Chemistry, 40, (2), 191-212. 
Brunello, A.J., Molotov, V.C., Dugherkhuu, B., Goldman, C., Khamaganova, E., Strijhova, T., Sigman, R. (2004). Lake Baikal: Lake Basin Management Initiative Experience and Lessons Learned Brief. 1 - 26.

Brumbaugh, W.G., Tillitt, D.E., May, T.W., Javzan, Ch., Komov, V.T. (2013). 'Environmental survey in the Tuul and Orkhon River basins of north-central Mongolia, 2010: metals and other elements in streambed sediment and floodplain soil.' Environmental Monitoring Assessment, 185, 8991 - 9008 .

Chalov, S.R., Jarsjö, J., Kasimov, N.S., Romanchenko, A.O., Pietron, J., Thorslund, J., Promakhova, E.V. (2015). 'Spatio-temporal variation of sediment transport in the Selenga River Basin, Mongolia and Russia.' Environmental Earth Sciences, 73, (2), 663 - 680.

Chalov, S., Thorslund, J., Kasimov, N., Aybullatov, D., Ilyicheva, E., Karthe, D., Kositsky, A., Lychagin, M., Nittrouer, J., Pavlov, M., Pietron, J., Shinkareva, G., Tarasov, M., Garmaev, E., Akhtman, Y., Jarsjo, J. (2016). 'The Selenga River delta: a geochemical barrier protecting Lake Baikal waters.' Regional Environmental Change, 17, (7), 2039 - 2053.

Ciesielski, T.M., Pastukhov, M.V., Leeves, S.A., Farkas, J., Lierhagen, S., Poletaeva, V.I., Jenssen, B.M. (2016). 'Differential bioaccumulation of potentially toxic elements in benthic and pelagic food chains in Lake Baikal.' Environmental Science and Pollution Research, 23, 15593 -

Corbitt, E.S., Jacob, D.J., Holmes, C.D., Streets, D.G., Sunderland, E.M. (2011). 'Global source-receptor relationships for mercury deposition under present day and 2050 emissions scenarios.' Environmental Science \& Technology, 45, (24), 10477-10484.

493 Crane, K., Hecker, B., Golubev, V. (1991). 'Heat flow and hydrothermal vents in Lake Baikal, 494 U.S.S.R.' Eos, 72, (52), 588-589. 
496 Engstrom, D.R., Balogh, S.J., Swain, E.B. (2007). 'History of mercury inputs to Minnesota 497 lakes: Influences of watershed disturbance and localised atmospheric deposition.' Limnology \& 498 Oceanography, 52, (6), 2467-2483.

Fitzgerald, W.F., Engstrom, D.R., Lamborg, C.G., Tseng, C-M., Balcom, P.H., Hammerschmidt, C.R. (2005). 'Modern and historic atmospheric mercury fluxes in northern Alaska: global sources and arctic depletion.' Environmental Science \& Technology, 39, 557-568.

French, T.D., Houben, A.J., Desforges, J-P.W., Kimpe, L.E., Kokelj, S.V., Poulain, A.J., Smol, J.P., Wang, X., Blais, J.M. (2014). 'Dissolved organic carbon thresholds affect mercury bioaccumulation in arctic lakes.' Environmental Science \& Technology, 48, 3162-3168.

Granina, L.Z., Klerkx, J., Callender, E., Leermakers, M., Golobokova, L.P. (2007). 'Bottom sediments and pore waters near a hydrothermal vent in Lake Baikal (Frolikha Bay).' Russian Geology and Geophysics, 48, (3), 237-246.

Gelety, V.F., Kalmykov, G.V., Parkhomenko, I.Y. (2007). 'Mercury in the sedimentary deposits of Lake Baikal.' Geochemistry International, 45, (2), 170-177. Environmental Science \& Technology, 40, 1204-1211.

523 Hampton, S.E., Gray, D.K., Izmest'eva, L.R., Moore, M.V., Ozersky, T. (2014). 'The Rise and 524 Fall of Plankton: Long-term changes in the vertical distribution of algae and grazers in Lake 525 Baikal, Siberia.' PLOS ONE, 9, (2), 1-10. 
527 Hampton, S.E., Moore, M.V., Ozersky, T., Stanley, E.H., Polashenski, C.M., Galloway, 528 A.W.E. (2015). 'Heating up a cold subject: prospects for under-ice plankton research in lakes.' 529 Journal of plankton research, 37, (2), 277 - 284.

Hintelmann, H., Welbourn, P.M., Evans, R.D. (1995). 'Binding of methylmercury compounds by humic and fluvic acids.' Water, Air and Soil Pollution, 80, 1031-1034. Journal of Great Lakes Research, 42, 6-17. contamination, erosion, and river loading of metals in a gold mining region of northern

543 Mongolia.' Regional Environmental Change, 17, 1991-2005.

Juggins, S. (2017). rioja: Analysis of Quaternary Science Data, R package version (0.9-15.1).

545 (http://cran.r-project.org/package=rioja).

Kasimov, N., Karthe, D., Chalov, S. (2017). 'Environmental change in the Selenga River - Lake Baikal Basin.' Regional Environmental Change, 17, 1945 - 1949.

549 Kaus, A., Schäffer, M., Karthe, D., Büttner, O., Tümpling, W., Borchardt, D. (2017).

550 'Regional patterns of heavy metal exposure and contamination in the fish fauna of the Kharaa 551 River basin (Mongolia).' Regional Environmental Change, 17, 2023 - 2037.

553 Kelly, C.A., Rudd, J.W.M., Holoka, M.H. (2003). 'Effect of pH on mercury uptake by an aquatic 554 bacterium: implications for Hg cycling.' Environmental Science Technology, 37, 2941-2946. 
556 Khanin, G.I. (2003). 'The 1950s - the triumph of the Soviet economy.' Europe-Asia Studies 55, $557 \quad 1187-5731212$.

Kipfer, R., Aeschbach-Hertig, W., Hofer, M., Hohmann, R., Imboden, D.M., Baur, H., Golubev, V., Klerkx, J. (1996). 'Bottom water formation due to hydrothermal activity in Frolikha Bay, Lake Baikal, eastern Siberia.' Geochimica et Cosmochimica Act, 60, (6), 961-971. L.D. (1999). 'Correlation of natural and technogenic mercury sources in the Baikal polygon, Russia.' Journal of Geochemical Exploration, 66, 277 - 289.

Leermakers, M., Meuleman, C., Baeyens, W. (1996). 'Mercury distribution and fluxes in Lake Baikal.' In: Global and Regional mercury cycles: sources, fluxes and mass balances. Eds Baeyens et al. Kluwer Academic Publishers. 303 - 315.

Logachev, N.A. (2003). 'History and geodynamics of the Baikal rift.' Russian Geology and Geophysics, 44, (5), $391-406$.

Lychagin, M.Y., Tkachenko, A.N., Kasimov, N.S., Kroonenberg, S. (2015). 'Heavy metals in 575 the water, plants, and bottom sediments of the Volga River mouth area.' Journal of Coastal Research 31, (4), 859-868.

Nadmitov, B., Hong, S., Kang, S.I., Chu, J.M., Gomboev, B., Janchivdorj, L., Lee, C-H., Khim, J, S. (2015). 'Large-scale monitoring and assessment of metal contamination in surface water of the Selenga River Basin (2007 - 2009).' Environmental Science and Pollution Research, 22, $2856-2867$.

Nikanorov, A.M., Reznikov, S.A., Mateev, A.A., Arakelyan, V.S. (2012). 'Monitoring of 584 Polycyclic Aromatic Hydrocarbons in the Lake Baikal basin in the areas of intensive anthropogenic impact.' Russian Meteorology and Hydrology, 37, (7), 477 - 484. 
587 Nomokonova, E., Lin, S-C., Chen, G. (2013). 'Investigation of safety compliance and safety participation as well as cultural influences: Using Selenginsk Pulp and Cardboard Mill in Russia as an example.' Proceedings of the Institute of Industrial Engineers Asian Conference Eds. YiKuei Lin, Yu-Chung Tsao, Shi-Woei Lin. Pp. 1001 - 1007.

Maruev, V.A. (2018). History of the gold-mining industry in the barring in the XIX-beginning of the XX century. Transbaikal State University, PhD thesis, 223 pp (in Russian).

Meuleman, C., Leermakers, M., Baeyens, W. (1995). 'Mercury speciation in Lake Baikal.' Water, Air and Soil Pollution, 80, 539 - 551.

Misyurkeeva, Yu. (2009). The barbarous "gold rush" in Mongolia poisons Selenga. Novaya Buryatiya 39, 12-14. (in Russian).

Moore, M.V., Hampton, S.E., Izmest'eva, L.R., Silow, E.A., Peshkova, E.V., Pavlov, B.K. (2009). 'Climate change and the world's “sacred sea" - Lake Baikal, Siberia.' Bioscience, 59, (5), $603405-417$.

O’Driscoll, N.J.O., Beauchamp, S., Siciliano, S.D., Rencz, A.N., Lean, D.R.S. (2003). 'Continuous analysis of dissolved gaseous mercury (DGM) and mercury flux in two freshwater lakes in Kejimkujik Park, Nova Scotia: Evaluating mercury flux models with quantitative data.' Environmental Science \& Technology, 37, 2226-2235.

Ozersky, T., Pastukhov, M.V., Poste, A.E., Deng, X.Y., Moore, M.V. (2017). 'Long-term and 611 ontogenetic patterns of heavy metal contamination in Lake Baikal seals (Pusa sibirica).' 612 Environmental Science \& Technology, 51, 10316 - 10325.

613

614 Pacyna, J.M., Travnikov, O., De Simone, F., Hedgecock, I.M., Sundseth, K., Pacyna, E.G., 615 Steenhuisen, F., Pirrone, N., Munthe, J., Kindbom, K. (2016). 'Current and future levels of 
616 mercury atmospheric pollution on a global scale.' Atmospheric Chemistry and Physics, 16, 12495

$617-12511$.

618

619 Perrot, V., Epov, V.N., Pastukhov, M., Grebenshchikova, V., Zouiten, C., Sonke, J.E.,

620 Husted, S., Donard, O.F.X., Amouroux, D. (2010). 'Tracing sources and bioaccumulation of 621 mercury in fish of Lake Baikal - Angara River using Hg isotopic composition.' Environmental 622 Science \& Technology, 44, (21), 8030 - 8037.

Perrot, V., Pastukhov, M.V., Epov, V.N., Husted, S., Donard, O.F.X., Amouroux, D. (2012). 'Higher mass-independent isotope fractionation of methylmercury in the pelagic food web of Lake Baikal (Russia).' Environmental Science \& Technology, 46, 5902-5911.

Pietron, J., Chalov, S.R., Chalova, A.S., Alekseenko, A.V., Jarsjö, J. (2017). 'Extreme spatial variability in riverine sediment load inputs due to soil loss in surface mining areas of the Lake Baikal basin.' Catena, 152, 82 - 93.

Ribeiro, C., Couto, C., Ribeiro, A.R., Maia, A.S., Santos, M., Tiritan, M.E., Pinto, E., Almeida, A.A. (2018). 'Distribution and environmental assessment of trace elements contamination of water, sediments and flora from Douro River estuary, Portugal.' Science of the Total Environment, 639, 1382-1393.

Roberts, S.L., Swann, G.E.A., McGowan, S., Panizzo, V.N., Vologina, E.G., Sturm, M., Siberia.' PLOS ONE, 13, (12), 1-20.

643 Rose, N.L., Appleby, P.G., Boyle, J.F., Mackay, A.W., Flower, R.J. (1998). 'The spatial and 644 temporal distribution of fossil-fuel derived pollutants in the sediment record of Lake Baikal, 645 eastern Siberia.’ Journal of Paleolimnology, 20, 151 - 162. 
647 Rose, N.L., Yang, H., Turner, S.D., Simpson, G.L. (2012). 'An assessment of the mechanisms

648 for the transfer of lead and mercury from atmospherically contaminated organic soils to lake 649 sediments with particular reference to Scotland, UK.' Geochemica et Cosmochimica Acta, 82, 113650135.

652 Scholz, C.A., Hutchinson, D.R. (2000). 'Stratigraphic and structural evolution of the Selenga 653 Delta Accommodation Zone, Lake Baikal Rift, Siberia.' International Journal of Earth Sciences, $65489,212-228$.

Silow, E.A., Krashchuk, L.S., Onuchin, K.A., Pislegina, H.V., Rusanovskaya, O.O., Shimaraeva, S.V. (2016). 'Some recent trends regarding Lake Baikal phytoplankton and zooplankton.' Lakes and Reservoirs and Management, 21, 40-44.

Sundseth, K., Pacyna, J.M., Pacyna, E.G., Pirrone, N., Thorne, R.J. (2017). 'Global sources and pathways of mercury in the context of human health.' International Journal of Environmental Research and Public Health, 14, 105, 1-14.

Swain, E.B., Engstrom, D.R., Brigham, M.E., Henning, T.A., Brezonik, P.L. (1992). 'Increasing rates of atmospheric mercury deposition in midcontinental north America.' Science, 257, 784-787.

Thorslund, J., Jarsjö, J., Chalov, S.R., Belozerova, E.V. (2012). 'Gold mining impact on 667 riverine heavy metal transport in a sparsely monitored region: the upper Lake Baikal Basin case.' Journal of Environmental Monitoring, 14, (10), 2780 - 2792. 'Speciation and hydrological transport of metals in non-acidic river systems of the Lake Baikal basin: Field data and model predictions.' Regional Environmental Change, 17, (7), 2007 - 2021.

674 Timoshkin, O.A., Samsonov, D.P., Yamamuro, M., Moore, M.V., Belykh, O.I.., Malnik, V.V. 
676 site of the world's greatest freshwater biodiversity in danger?' Journal of Great Lakes Research,

677 42, (3), 487-497.

Törnqvist, R., Jarsjö, J., Pietron, J., Bring, A., Rogberg, P., Asokan, S.M. (2014). ‘Evolution of the hydro-climate system in the Lake Baikal basin.' Journal of Hydrology, 519, 1953-1962.

Tumenbayer, B., Batbaya, M., Grayson, R. (2000). 'Environmental hazard in Lake Baikal watershed posed by mercury placer in Mongolia.' World Placer Journal, 1, 134-159.

United Nations Environmental Programme (UNEP) Global Mercury Assessment. (2013).

'Global Mercury Assessment 2013 Sources, Emissions, Releases and Environmental Transport. UNEP Chemicals Branch, Geneva, Switzerland.

United Nations (UN) Environment. (2017). 'Minamata Convention on Mercury.' www.mercuryconvention.org

United States Environmental Protection Agency. (2002). Method 1631, Revision E: Mercury 693 in water by oxidation, purge and trap, and cold vapor atomic fluorescence spectrometry. 694 Washington, D.C, United States of America.

Vasiliev, O.F., Obolenskiy, A.A., Yagolnitser, M.A. (1998). 'Mercury as a pollutant in Siberia: sources, fluxes and a regional budget.' The Science of the Total Environment, 213, 73-84.

Wan, D., Song, L., Mao, X., Yang, J., Jin, Z., Yang, H. (2019). ‘One-century sediment records of heavy metal pollution on the southeast Mongolian Plateau: Implications for air pollution trend 701 in China.' Chemosphere, 220, 539-545.

703 Yang, H., Rose, N.L., Battarbee, R.W. (2002). 'Mercury and lead budgets for Lochnagar, a 704 Scottish Mountain Lake and its catchment.' Environment, Science \& Technology, 36, 1383-1388. 
706 Yang, H., Engstrom, D.R., Rose, N.L. (2010a). 'Recent changes in atmospheric mercury 707 deposition recorded in the sediments of remote equatorial lakes in the Rwenzori mountains, 708 Uganda.' Environmental Science \& Technology, 44, 6570 - 6575.

710 Yang, H., Battarbee, R.W., Turner, S., Rose, N.L., Derwent, R.G., Wu, G., Yang, R. (2010b).

711 'Historic reconstruction of mercury pollution across the Tibetan Plateau using lake sediments.'

712 Environmental Science \& Technology, 44, 2918-2924.

713. Yang, H., Smyntek, P. (2014). 'The mercury record in Red Tarn sediments reveals air pollution

714 history and implications of catchment erosion.' Environment Science: Processes and Impacts, 16, 715 (11).

717 Yang, H. (2015). 'Lake sediments may not faithfully record decline of atmospheric pollutant 718 deposition.' Environmental Science \& Technology, 49, (21), 12607-12608. Yoshioka, T., Ueda, S., Khodzher, T., Bashenkhaeva, N., Korovyakova, I., Sorokovikova, L.,

721 Gorbunova, L. (2002). 'Distribution of dissolved organic carbon in Lake Baikal and its 722 watershed.' Limnology, 3, 159-168.

724 Zhao, L., Qingbai, W., Marchenko, S.S., Sharkhuu, N. (2010). 'Thermal state of permafrost 725 and active layer in central Asia during the international polar year.' Permafrost and periglacial processes, 21, 198-207. 


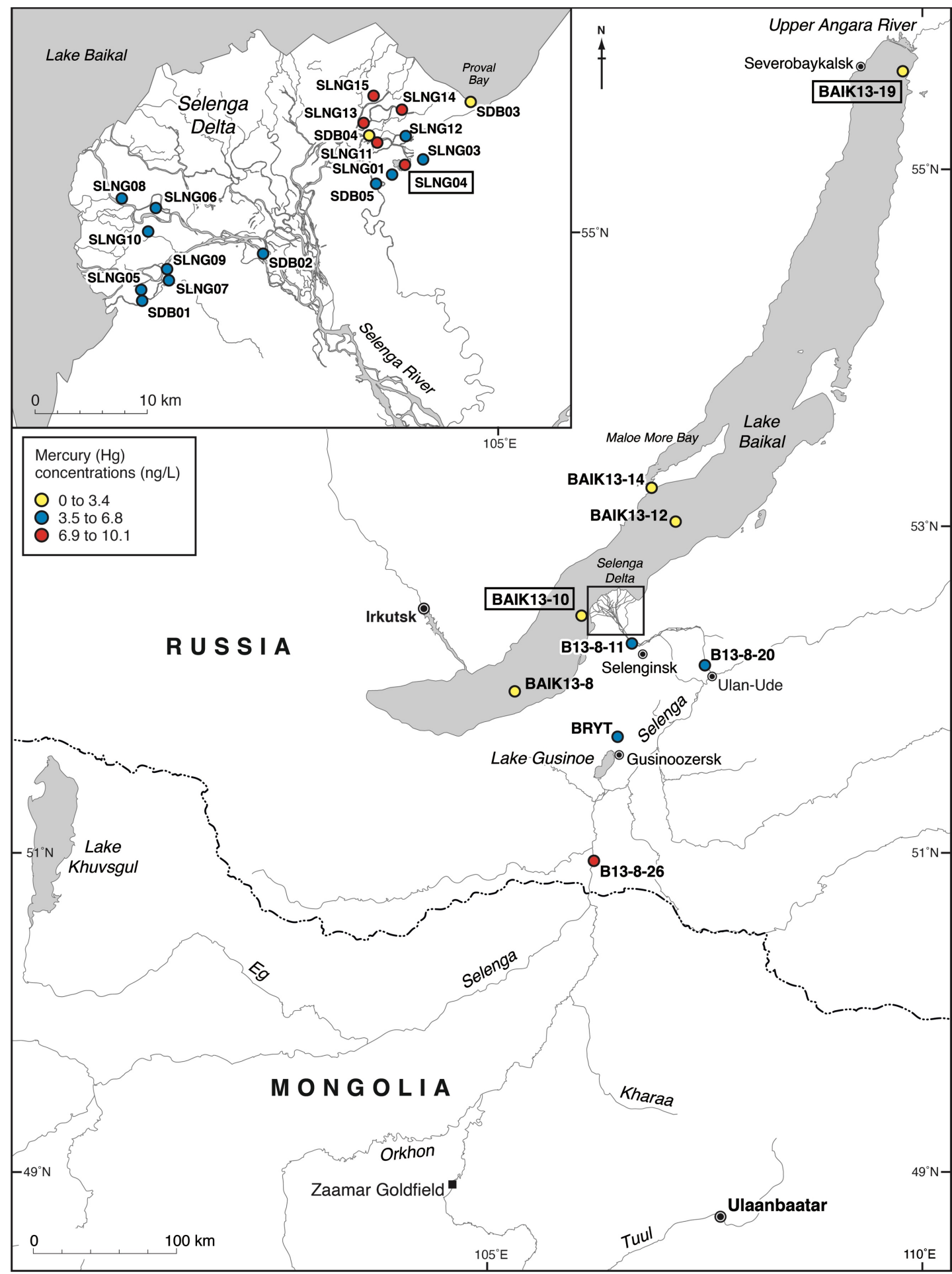

764 Fig 1. Location of study sites and other key locations referred to in the text across Lake 765 Baikal and the Selenga River catchment. Mercury (Hg) concentrations (ng/L) in surface 766 water samples collected from the Selenga River, Selenga Delta and Lake Baikal. 
(C) Selenga Delta [SLNG04]

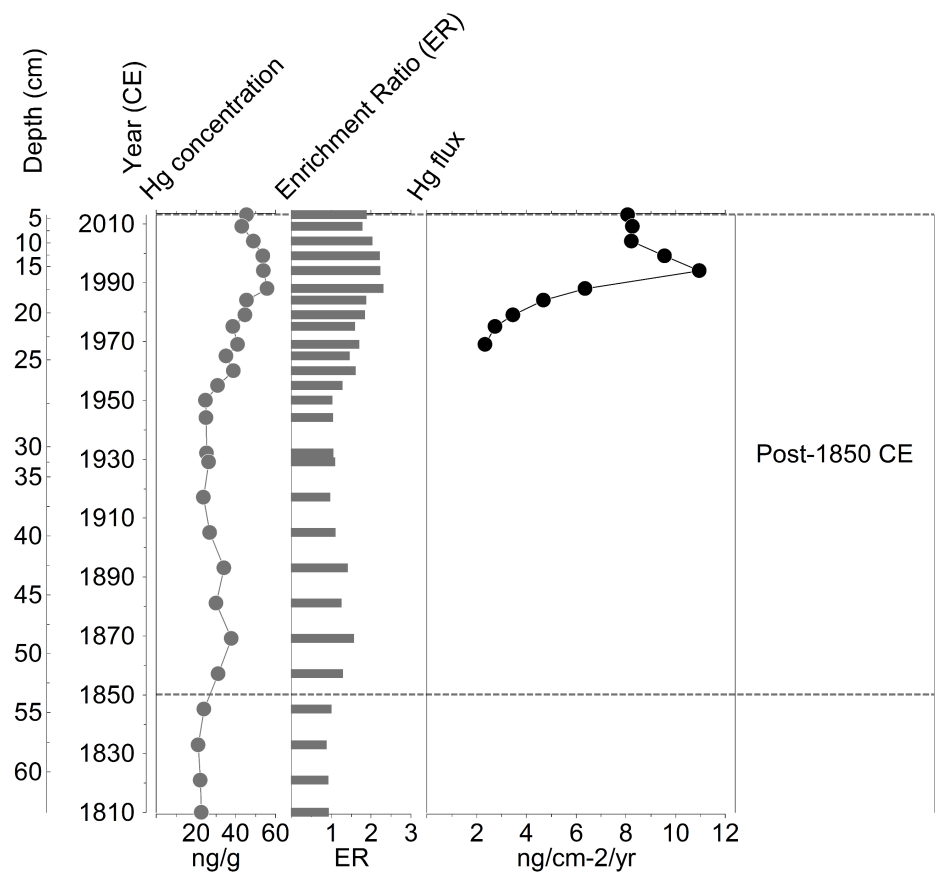

782 Fig 2. Sedimentary mercury (Hg) concentrations (ng/g), enrichment ratios (ER) and Hg 783 fluxes (ng/cm²/yr) profiles from the (A) south basin [BAIK13-10], (B) north basin [BAIK13784 19] in Lake Baikal and (C) Selenga Delta [SLNG04]. For SLNG04 all the dates beyond c. 7851945 are extrapolations of constant background sedimentation rates pre-1980. 